\title{
APPENDIX V. A MARINE GEOPHYSICAL SURVEY IN THE VICINITY OF DSDP SITE 245, MADAGASCAR BASIN; INDIAN OCEAN ${ }^{1}$
}

\author{
Bhoopal Naini and John Chute, ${ }^{2}$ Lamont-Doherty Geological Observatory of Columbia University, Palisades, New York
}

\begin{abstract}
The Madagascar Basin in the vicinity of DSDP Site 245 is characterized by topography that exhibits a regional northeastsouthwest trend along with a local west northwest-east southeast trend. Locally, the free-air gravity anomaly field pattern is conformable in the south and subparallel to nearly perpendicular to this pattern in the north. Two sets of magnetic anomaly patterns associated with the generation of sea floor from the Southwest Indian Ridge in the south and from the Central Indian Ridge in the north is suggested. Seismic stratigraphy reveals the presence of at least two poorly stratified, nearly transparent layers with a total thickness of about 0.6 seconds. The basement is comparatively smooth with isolated peaks and local faults. The sediment distribution and the basement ridges have a trend similar to that of the Southwest Indian Ridge.
\end{abstract}

\section{INTRODUCTION}

A detailed marine geophysical site survey of approximately $1^{\circ} \times 1^{\circ}$ area in the southwestern Indian Ocean was carried out by Lamont-Doherty Geological Observatory during its R/V Robert D. Conrad Cruise 14 in February 1971. Location of the site and details of the track are given in Figures 1 and 2, respectively. This survey was intended as an aid in choosing a possible site for the Deep Sea Drilling Project in the Indian Ocean. The area was tentatively selected on the basis of an earlier reconnaissance survey carried out by R/V Robert D. Conrad Cruise 11 in March 1967. Subsequently, in August of 1972, the site was drilled (Holes 245 and 245A, DSDP Leg 25, Simpson et al., 1972).

The survey area lies in the southern Madagascar Basin, about 200 miles northwest of the Southwest Indian Ridge axis. The Conrad-11 reconnaissance survey indicated that the area is made up of comparatively smooth basement with local faulting. According to the bathymetric charts of the Indian Ocean (Fisher, in press), the Madagascar Basin is outlined by a smooth 4500 -meter isobath. There are no published accounts of magnetic anomaly identifications in the area of study. Schlich and Patriat (1971a, 1971b) have published magnetic anomaly identification in areas southwest and southeast of the site location that account for the history of spreading back to $15 \mathrm{~m} . \mathrm{y}$. and $35 \mathrm{~m} . \mathrm{y}$., respectively. McKenzie and Sclater (1971) have shown in their summary diagram of identified magnetic anomalies in the Madagascar Basin, the location of older anomalies. The existence of these older anomalies (23 to 28 ) in the Madagascar Basin was pointed out to these authors by Schlich and Patriat (1971c.) According to this identification, DSDP Site 245 could be located over an oceanic

\footnotetext{
${ }^{1}$ Lamont-Doherty Geological Observatory Contribution No. 2022 .

${ }^{2}$ Also at Herbert H. Lehman College, CUNY, Bronx, N.Y.
}

crust formed during magnetic anomaly 28 (68 m.y.) of Heirtzler et al. (1968) time scale (Simpson et al., 1972.) Details of the Cruise 14 site survey are discussed in the following pages.

\section{SURVEY RESULTS}

\section{Topography}

A detailed topographic map of the study area, contoured at 100-meter intervals from soundings in corrected meters, is shown in Figure 3. There is no uniform topographic pattern in the survey area. However, the northern half of the area seems to have a broad west-northwest-east southeast trend, and the southern half a northeastsouthwest trend. The total relief in the area is on the order of 1300 meters with the shoalest part being about 4000 meters and the deepest part about 5300 meters. The dominant trend in the southern part of the area is similar to the regional trend of the Southwest Indian Ridge, whereas the trends of deeps in the northern part seem to be crescentic in shape. The overall topography dips gently to the north.

\section{Gravity}

Free-air gravity anomaly values in the study area plotted along the ship's track and contoured at convenient intervals are presented in Figure 4. A broad northeast-southwest trend is noticeable on this map. This trend is closely conformable with that of the topography in the southern part of the area. However, in the north this gravity trend is subparallel to nearly perpendicular to that of the topography. The total range of the free-air gravity values over the area is of the order of $50 \mathrm{mgal}$. The zero-mgal contour divides the study area into three parts: a corner along the southeast with positive values reaching a maximum of about $35 \mathrm{mgal}$; a corner along the northwest with positive free-air values reaching up to $7 \mathrm{mgal}$; and the 


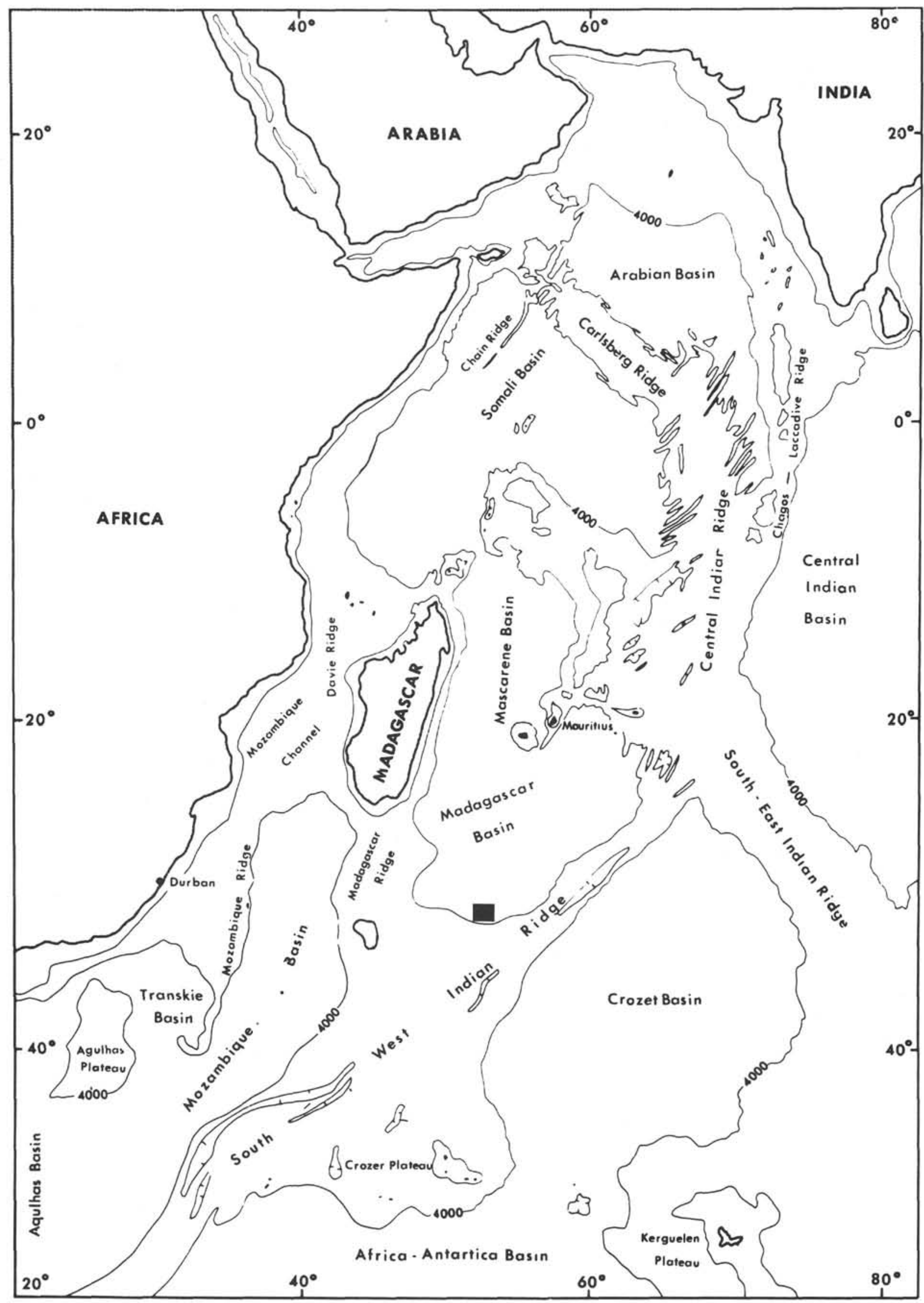

Figure 1. Generalized bathymetric sketch of the western Indian Ocean with 4000-meter isobath outlining the major topographic features with location of study area in black square. 


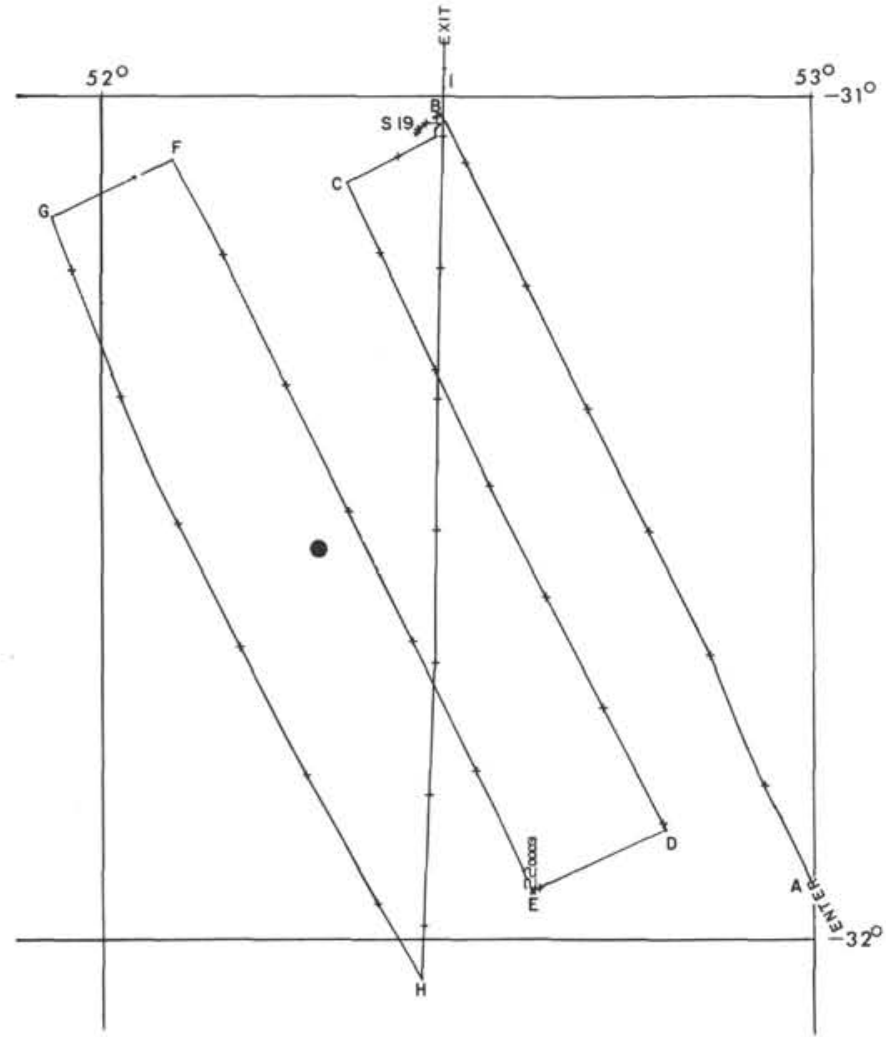

Figure 2. Details of the track for the site survey. Time marked every hour on the hour with plus signs, satellite fixes once a day marked by day and time. Numeral with prefix $\mathrm{S}$ corresponds to ship's station. $\mathrm{AB}, \mathrm{CD}$, etc., are locations of seismic reflection profiles of Figure 6. Black circle (also on Figures 3, 4, 5, and 7) is the location of DSDP Site 245.

intervening part, covering nearly 70 percent of the area, with negative values and two isolated minima of $-15 \mathrm{mgal}$ and -10 mgal, respectively. The gravity trend observed here is conformable with the regional free-air field trend of the Southwest Indian Ridge (Talwani and Kahle, in press.) The zero-mgal contour in the northern part of this area conforms with the regional field of the Madagascar Basin. The two positive zones described above reflect the positive free-air gravity field associated with the Southwest Indian Ridge and the Madagascar Ridge (Kahle and Talwani, 1973.) The broad central negative zone reflects the gravity field associated with the Madagascar Basin.

\section{Magnetics}

The residual total intensity magnetic anomaly values are plotted along the ship's track and contoured at 50-gamma intervals (Figure 5). The total anomaly range is about 550 gammas. The presence of two different trends is indicated. In the southern part of this area, an east-northeast-westsouthwest trend is present. The northern and western part of the area, however, represents a broad west-northwesteast-southeast trend. The first of these trends is nearly similar to the trends of topography and gravity for the same part of the area; this is also the trend of the Southwest Indian Ridge. However, the second trend is entirely different from those of the topography and gravity and the basement (even though the basement topography is not presented here, it could easily be visualized as parallel to bottom topography since the trends of both topography and sediment isopachs are similar) suggests that it is possibly reflecting the direction of remanent magnetization of basement rocks. There are no published accounts of anomaly identification in this region. Schlich and Patriat (1971c) and McKenzie and Sclater (1971) identified up to anomaly 26 northeast of here; this extends up to about $29^{\circ} \mathrm{S}$ and $55^{\circ} \mathrm{E}$. Furthermore, they delineated a fracture zone that trends northeast-southwest and offsets these anomalies in a dextral sense. It is interesting to note that the apparent trend of the magnetic anomaly pattern defined in the northern part of the study area corresponds to the trends of the identified anomalies described above. According to these identifications, DSDP Site 245 could be located over anomaly 28 (68 m.y.B.P.), and the location of the site on the magnetic map of the study area (Figure 5) is within the west-northwest-east-southeast trending pattern. These might imply that the identified magnetic anomaly pattern (Schlich and Patriat, 1971c and McKenzie and Sclater, 1971) may be extended to the southwest; at least up to the latitudes of this study. The two magnetic anomaly patterns found here, viz., west-northwest-eastsoutheast and east-northeast-west-southwest, suggest that the former pattern is associated with the crustal generation at the Central Indian Ridge, which was later displaced by the activation of the Southwest Indian Ridge that gave rise to the latter pattern.

\section{Seismic Reflection Profiles}

Seismic reflection profiles along the ship's track are presented in Figures $6 \mathrm{a}$ through $6 \mathrm{e}$. It will be noted that there are two conspicuous subbottom reflectors dividing the section into two major sedimentary layers. The topmost is a poorly stratified acoustically transparent layer attaining a thickness of about 0.1 second $(\sim 100 \mathrm{~m}$ thick, assuming a mean velocity of $2.0 \mathrm{~km} / \mathrm{sec}$ ) that locally thins and pinches out over basement highs. Underlying this is a thicker layer of similar acoustic nature that reaches up to about 0.5 second in thickness. There is a third discontinuous and poorly defined layer underlying the above sediment that is relatively thin and acoustically more opaque. This sedimentary sequence is underlain by a basement that is comparatively smooth for the most part but also shows isolated peaks, scarps and horst and graben-like features.

Sediment isopachs for this area were contoured at $0.1-\mathrm{sec}$ intervals based on readings of two-way reflection time. Values were plotted every 10 minutes $(0.3 \mathrm{~km})$ along the ship's track (Figure 7). The thickness of the sediment varies between zero and $0.6 \mathrm{sec}$. The thickest sediment is concentrated along the basement depressions. The overall sediment distribution pattern has an approximate northeast-southwest trend, similar to the trend of basement ridges. These ridges extend as long linear features with basement outcrops often forming isolated highs. The overall sediment distribution and basement trend reflect the regional trend of the Southwest Indian Ridge. 


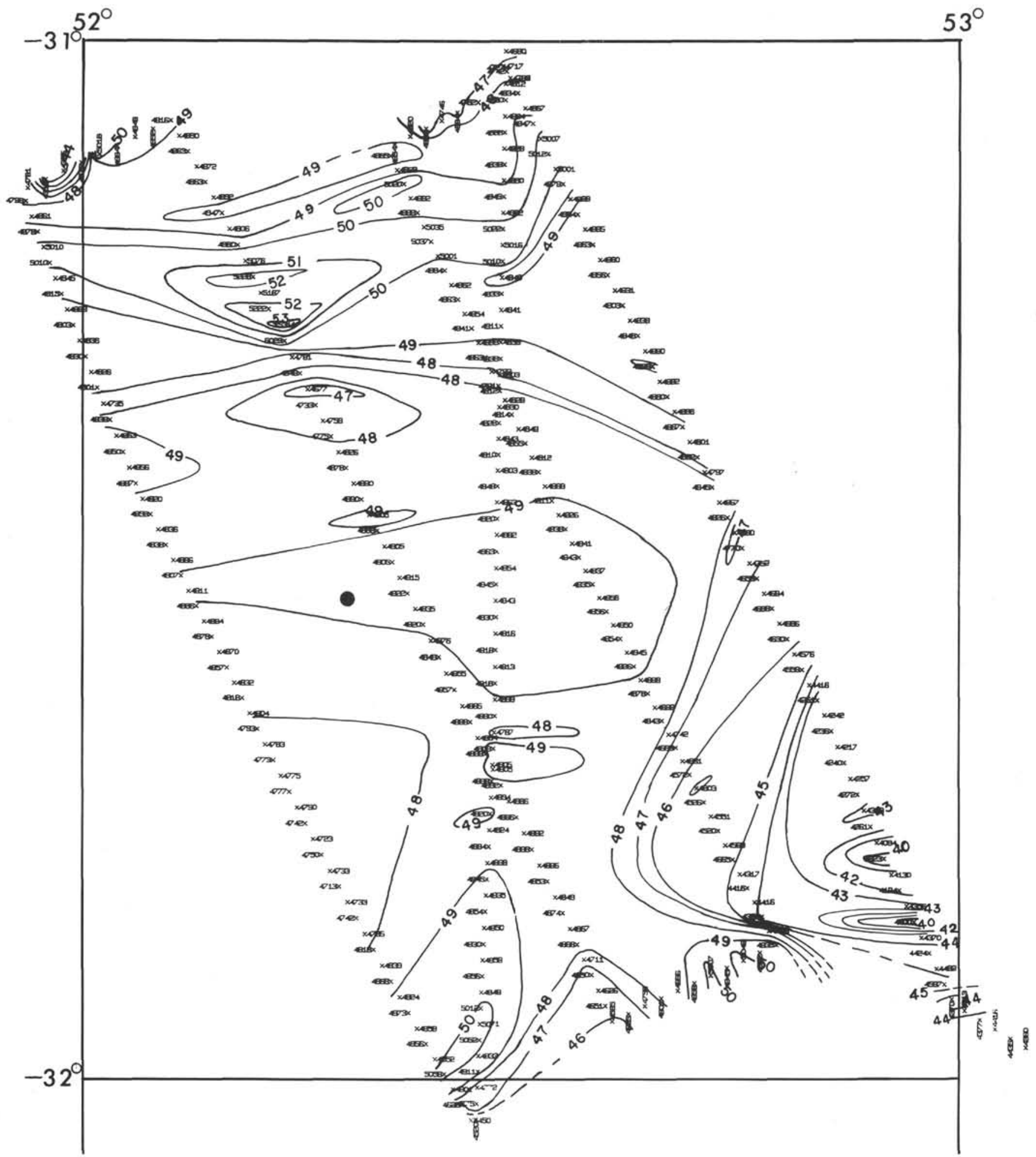

Figure 3. Bathymetric soundings in corrected meters in the survey area plotted along the ship's track and contoured in hundreds of meters at 100-meter intervals. 


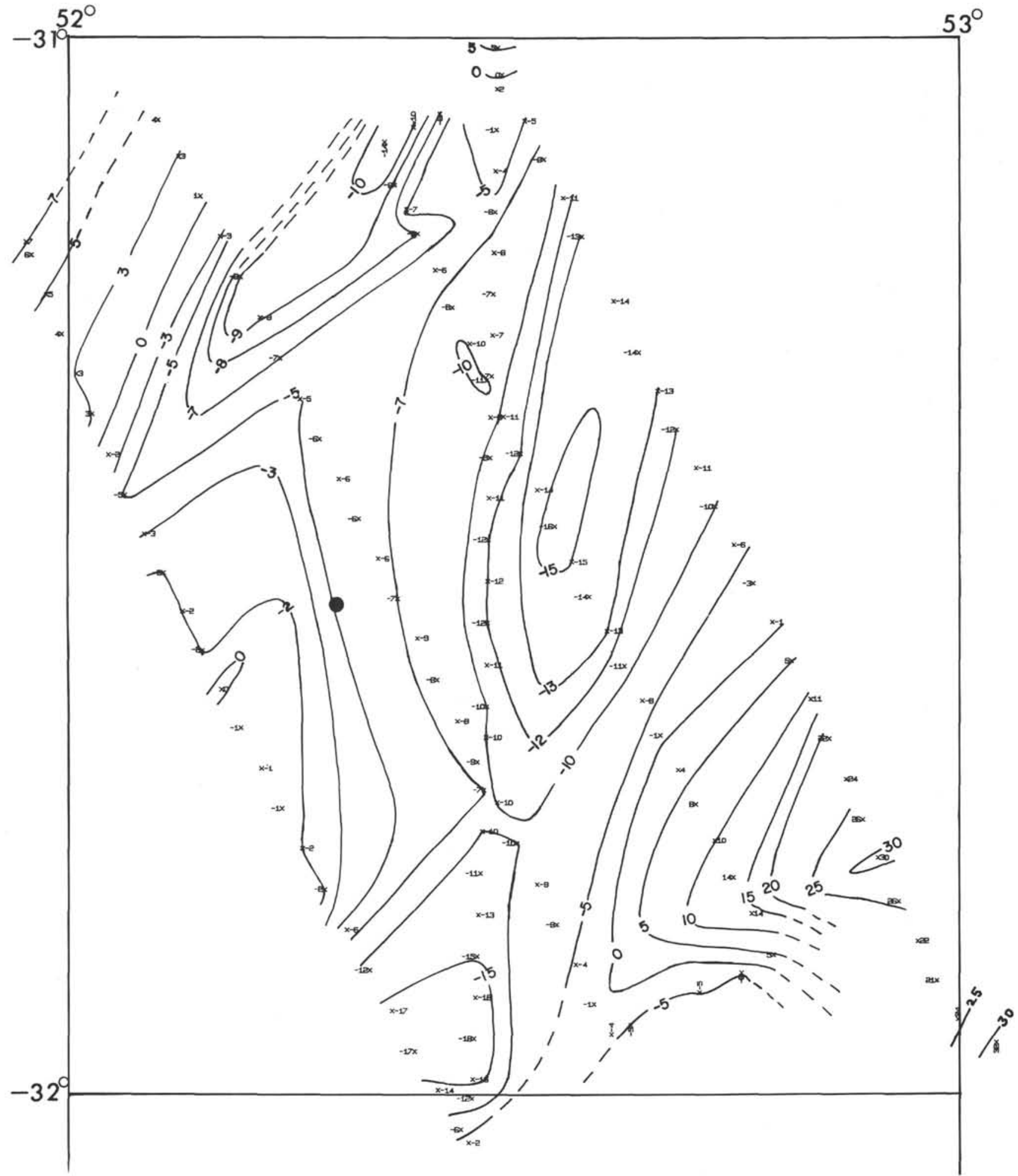

Figure 4. Free-air gravity anomaly map of the survey area, with values plotted along ship's track and contoured at variable intervals. 


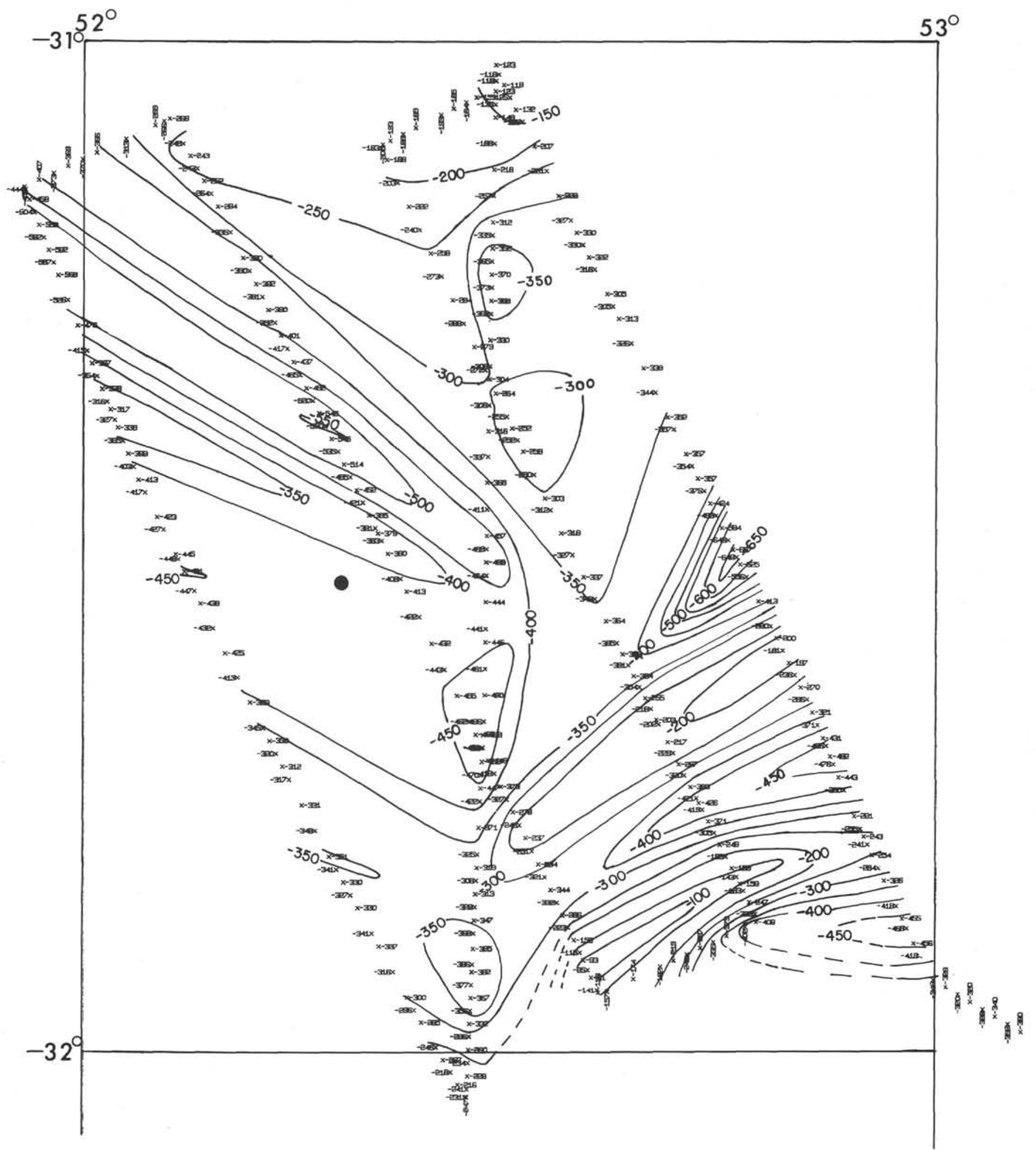

Figure 5. Residual total intensity magnetic anomalies in the survey area plotted along the ship's track and contoured at 50-gamma intervals. 


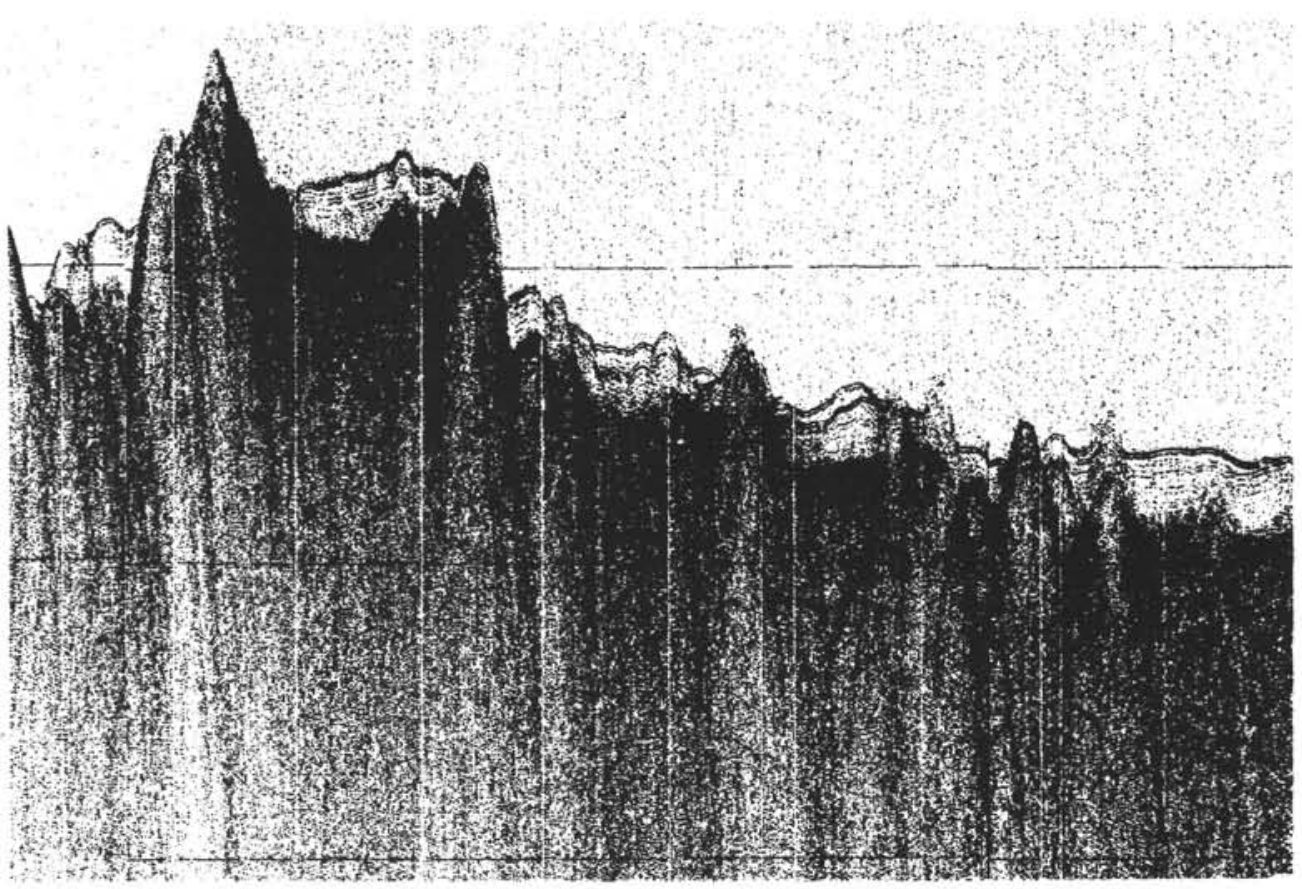

A

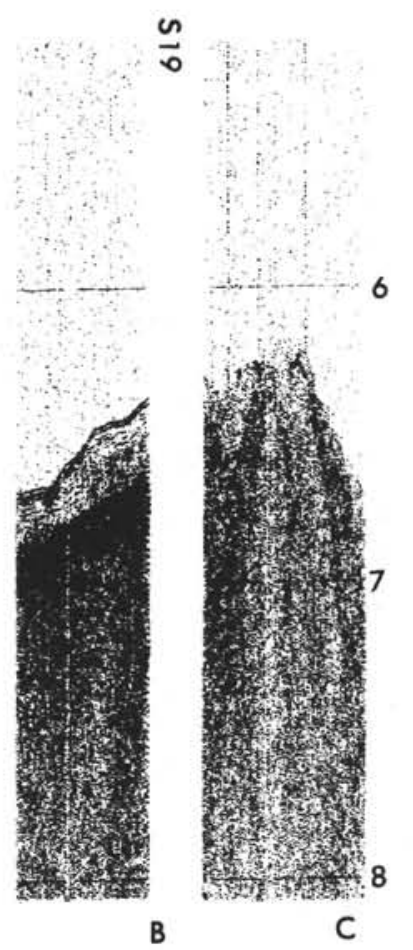

B

Figure 6a. Low-frequency airgun seismic reflection profiles along the sections of Figure 2 showing numerous features described in the text. Vertical scale is two-way reflection time in seconds.

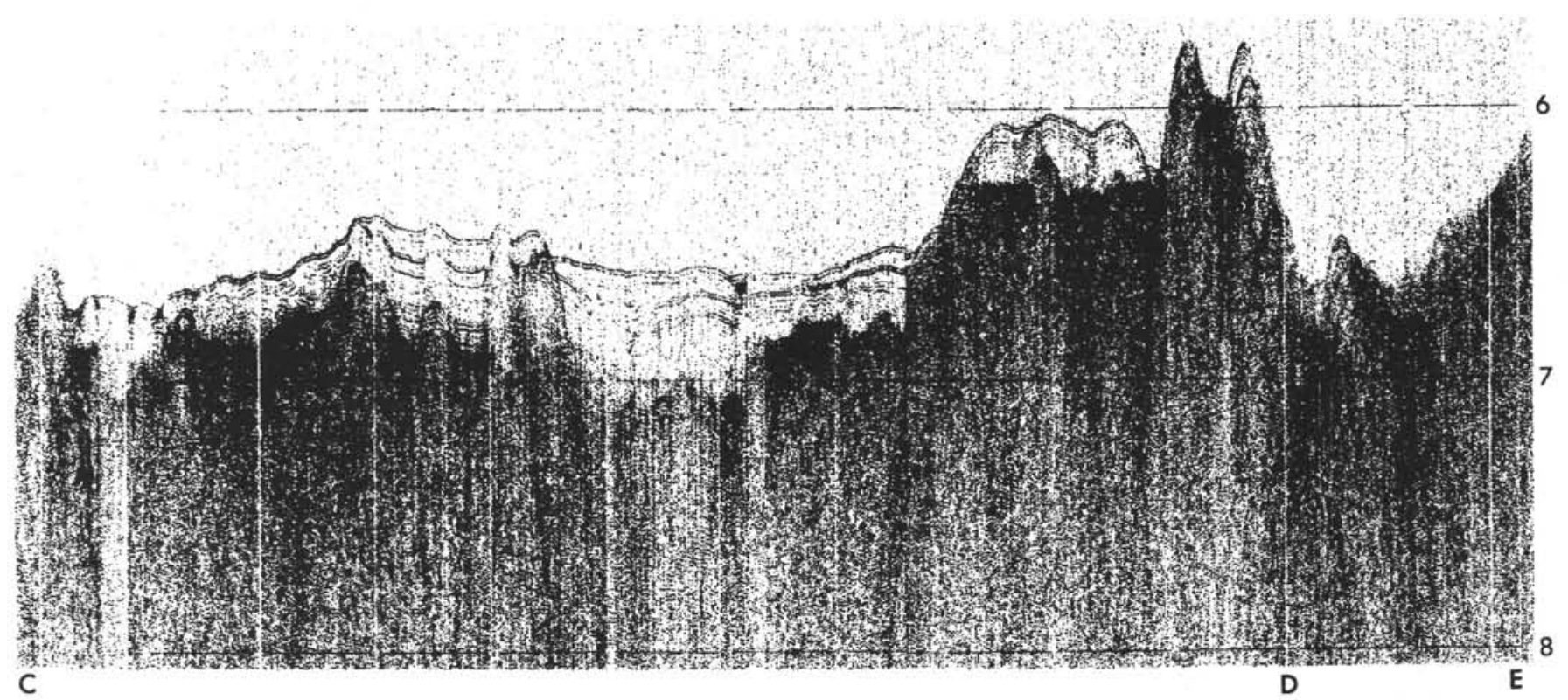

Figure 6b. Low-frequency airgun seismic reflection profiles along the sections of Figure 2 showing numerous features described in the text. Vertical scale is two-way reflection time in seconds. 

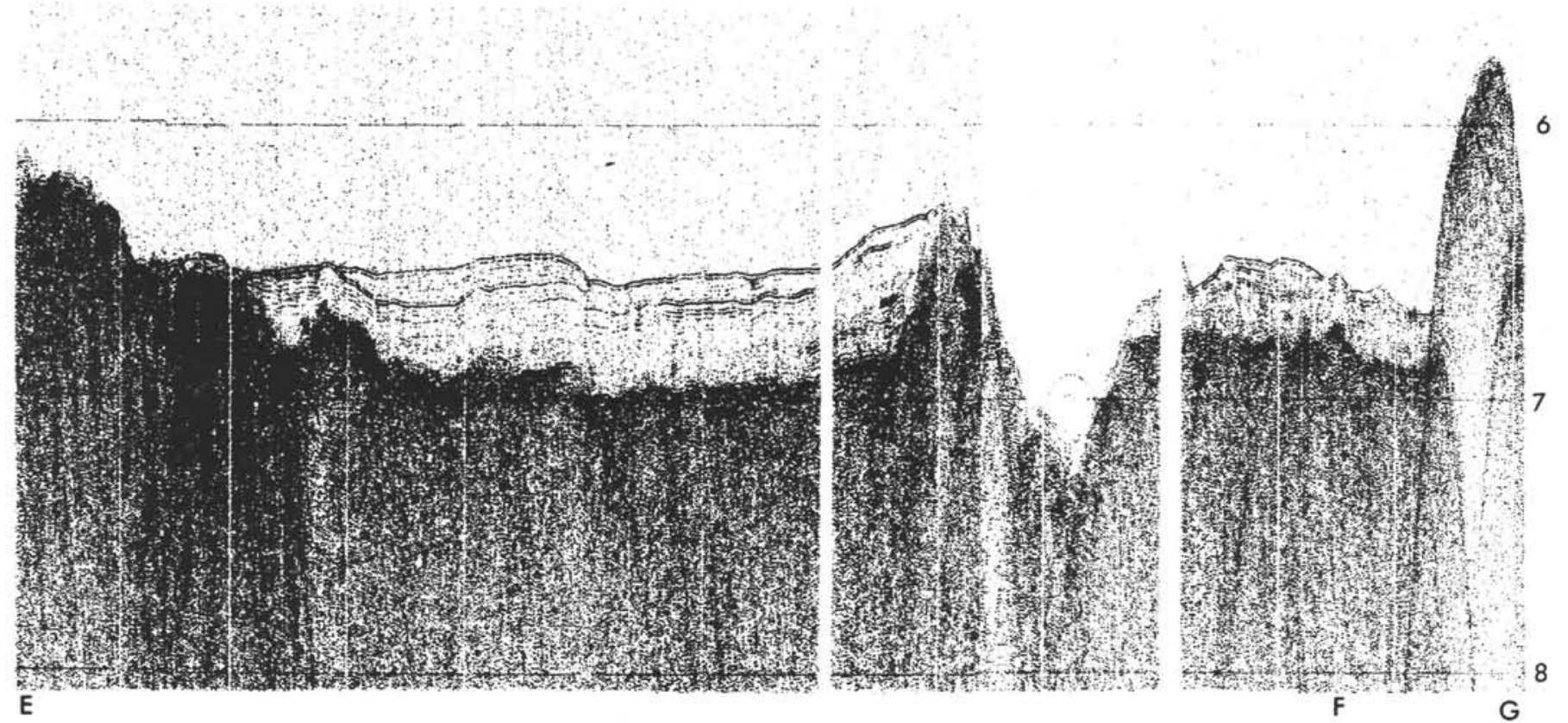

Figure 6c. Low-frequency airgun seismic reflection profiles along the section of Figure 2 showing numerous features described in the text. Vertical scale is two-way reflection time in seconds.

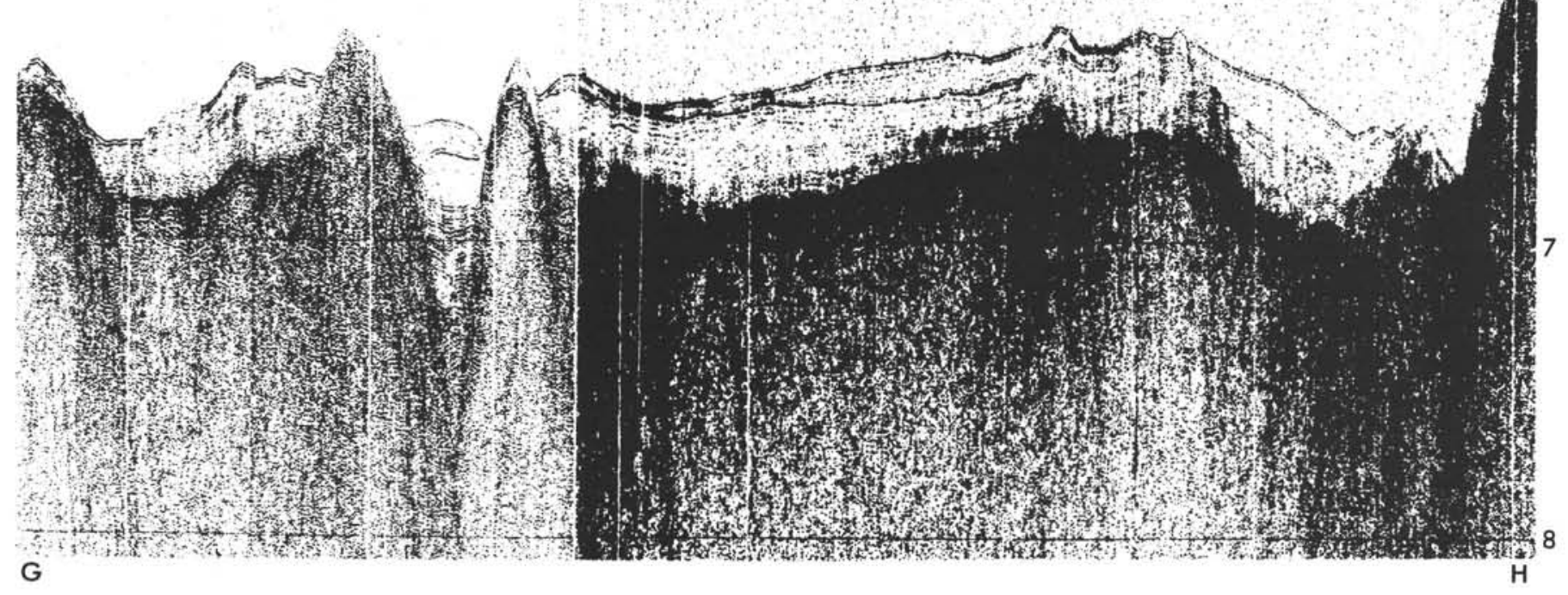

Figure 6d. Low-frequency airgun seismic reflection profiles along the section of Figure 2 showing numerous features described in the text. Vertical scale is two-way reflection time in seconds. 


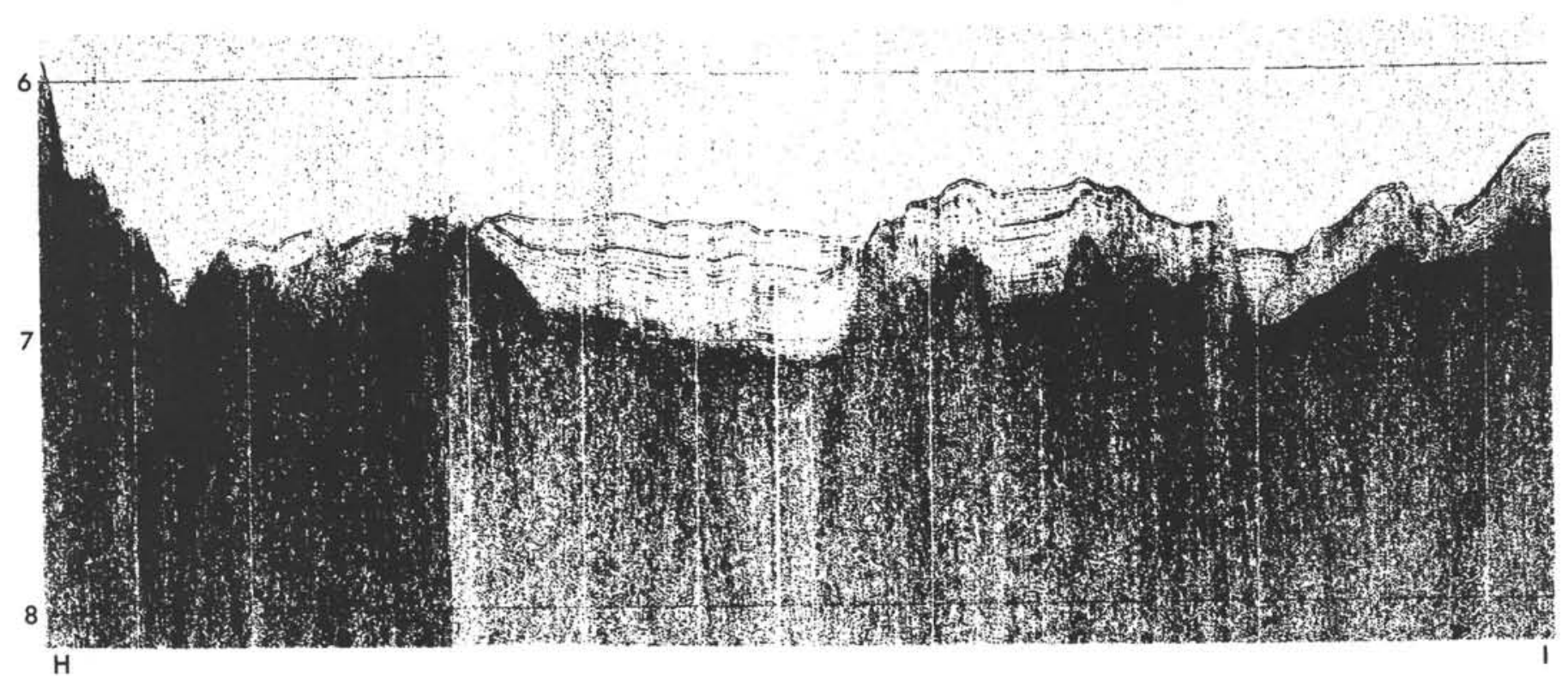

Figure 6e. Low-frequency airgun seismic reflection profiles along the sections of Figure 2 showing numerous features described in the text. Vertical scale is two-way reflection time in seconds.

\section{Bottom Sampling}

A piston core was collected at Station 19 (Figures 2, $6 \mathrm{~b})$. The $494-\mathrm{cm}-$ long core consisted mostly of clay with a coarse fraction made up of planktonic foraminifera, echinoid spines, sponge spicules, dark minerals, fish teeth and shell fragments; with no carbonate content. The dating of the foraminifera indicates an upper Paleocene age (T. Saito, personal communication) at the base of this core.

\section{CONCLUSIONS}

This work has revealed that:

1) The area of study has no single uniform topographic pattern; instead it has a broad west-northwest-eastsoutheast trend in the north and a northeast-southwest trend in the south.

2) The free-air gravity anomaly trend is conformable in the south to subparallel to nearly perpendicular with the topographic trends in the north.

3) The magnetic anomaly pattern has two distinct trends; the one in the south, with an approximate eastnortheast-west-southwest trend, is conformable with the trend of the Southwest Indian Ridge, and the other, in the northern and western parts of the area, has an approximate west-northwest-east-southeast trend and seems to be part of the trend associated with the crustal generation at the Central Indian Ridge.

4) Seismic stratigraphy indicates the presence of at least two sedimentary layers, with a total thickness reaching up to 0.6 second, which are underlain by basement.

5) Overall basement topography is comparatively smooth and consists of faults, isolated peaks, and horst and graben type features.

6) Sediment distribution and the basement ridge pattern have a trend similar to that of the regional topography of the Southwest Indian Ridge.

\section{ACKNOWLEDGMENTS}

We thank Dr. Jeffrey Weissel and Mr. Charles Windisch for their critical review of the manuscript. We are grateful to $\mathrm{Mr}$. John Ewing for the encouragement given in carrying

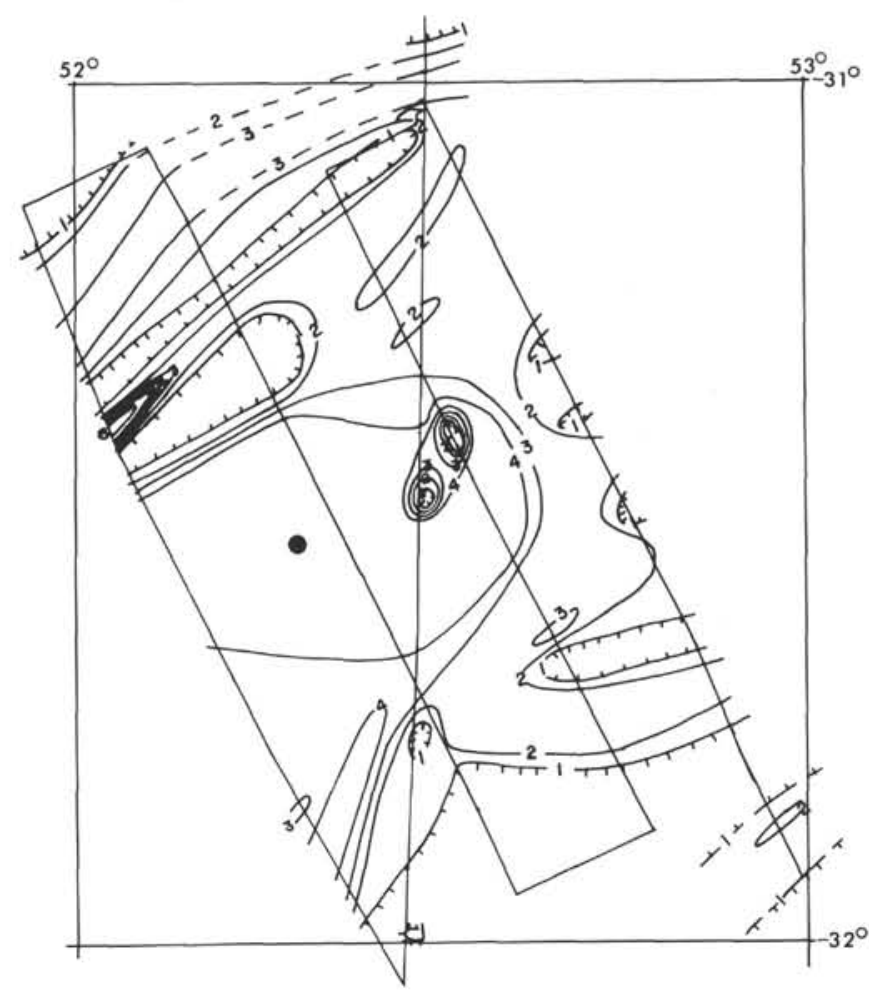

Figure 7. Sediment isopach map of the survey area based on readings of two-way travel time through the sediment at ten-minute intervals and contoured at 0.1-second intervals. Hachures are toward basement outcrops. 
out this work. Thanks are also due to the officers and crew of the R/V R. D. Conrad, and in particular, to Dr. Eric Simpson of the University of Cape Town, South Africa, for participation as a visiting scientist; and to Miss Betty Batchelder for editorial help.

Support for this work came from grants GA27281 and GA28338 from the National Science Foundation, and the Office of Naval Research contract N00014-67-A0108-0004.

\section{REFERENCES}

Fisher, R. L., in press. Bathymetric charts in the Indian Ocean. In Udintsev, G. (Chief Ed.), The International Indian Ocean Expedition Atlas of Geology and Geophysics.

Heirtzler, J. R., Dickson, G. O., Herron, E. M., Pitman, W. C., III, and Le Pichon, X., 1968. Marine magnetic anomalies, geomagnetic field reversals and motion of the ocean floor and continents: J. Geophys. Res., v. 73, p. 2119-2136.

Kahle, H. G. and Talwani, M., 1973. Gravimetric Indian Ocean geoid: Zeitschr. für Geophysik, v. 39, no. 1, p. 167-187.
McKenzie, D. and Sclater, J. G., 1971. The evolution of the Indian Ocean since the Late Cretaceous. Roy. Astron. Soc. J., v. 25 , p. 437-528.

Schlich, R. and Patriat, P., 1971a. Mise en évidence d'anomalies magnétiques axiales sur la branche ouest de la dorsale médio-indienne (Note): Physique du Globe, série D, C. R. Acad. Sci. Paris, v. 272, p. 700-703. 1971b. Anomalies magnétiques de la branche Est de la dorsale médio-indienne entre les isles Amsterdam et Kerguelen (Note): Physique du Globe, serie B, C. R. Acad. Sc. Paris, v. 272, p. 773-776. 1971c. Expansion des fonds océaniques dans l'Ocean Indien Austral: Communication presentée à la XVe Assemblée Générale de l'U.G.G.I., Moscow, 1971. Simpson, E., Schlich, R., LeClaire, L., Moore, C., Girdley, W. A., White, S. M., Vallier, T., Muller, C., Zobel, B., Sigal, J., Gieskes, J., and Marshall, B. V., 1972. Leg 25 DSDP. western Indian Ocean: Geotimes, v. 17, no. 11, p. 21-24.

Talwani, M. and Kahle, H., in press. Free-air gravity maps in the Indian Ocean. In Udintsev, G. (Chief Ed.), The International Indian Ocean Expedition Atlas of Geology and Geophysics. 